\title{
A comparison of civil religion and remembrance culture in Germany and Japan
}

\author{
Carmen Schmidt(iD
}

Correspondence: carmschm@uos.de School of Cultural Studies and Social Sciences, FB 1/Japan Research Center, University of Osnabrueck, Seminarstrasse 33, Osnabrueck 49074, Germany

\begin{abstract}
Japan and Germany were allies during World War II, and both countries committed crimes. Even though the Nazi persecution of Jews in Germany was unprecedented in history, Japan has also been found guilty of serious misdemeanours. Today, Germany acknowledges the magnitude of its responsibility and strives to deal with this legacy. However, in Japan, we find no consensus on dealing with the matter. Nonetheless, it would be short-sighted to conclude that Germany did a better job than Japan from the outset. In analysing the different approaches to remembrance culture in the two countries, we use the theoretical framework of civil religion to assess the impacts of the respective civil religions on the culture of commemoration. We hereby analyzed the structural factors as well as the influence of individual political behaviour. Immediately after the war, neither Germany nor Japan were interested in coming to terms with their past. Both countries were subject to Western integration, and both countries experienced remarkable economic growth. One of the major differences between both countries concerns civil religion. While Germany no longer relied on strong nationalism-based politics and instead pursued European integration, in Japan. Shintôism has continued to influence feelings of national belonging, making it more difficult to establish a critical dialogue with the past. Further differences are apparent: the Western origin of Japan's constitution, the conflicting international environment in Japan, the late regime change, differences in education and, most importantly, the impacts of generational change in Germany. The 1968 student generation strongly condemned Nazi aggression and demanded that the older generation face responsibility, which strongly contributed to a reappraisal of the past in the public sphere.
\end{abstract}

Keywords: Civil religion, Remembrance culture, Japan, Germany, 1968 student protests

\section{Introduction}

Japan and Germany were allies during World War II, and both countries committed crimes, especially in neighbouring countries. Although the Nazi persecution of Jews in Germany was unprecedented in history, Japan has also been found guilty of serious crimes, such as the massacre of Nanjing and forced prostitution, which is discussed as the 'comfort women' issue. ${ }^{1}$

In its official politics, Germany acknowledges the magnitude of its responsibility for some of the worst crimes in European history, and strives to deal with this

(C) 2016 The Author(s). Open Access This article is distributed under the terms of the Creative Commons Attribution 4.0 International License (http://creativecommons.org/licenses/by/4.0/), which permits unrestricted use, distribution, and reproduction in any medium, provided you give appropriate credit to the original author(s) and the source, provide a link to the Creative Commons license, and indicate if changes were made. 
legacy. However, in Japan, we find no consensus on dealing with war crimes. Although several efforts were made to address the past or even to apologise, the official government position remains unclear. During her visit in Japan in March 2015, the German Chancellor, Merkel, urged Japan to confront its wartime conduct, citing Germany's ability to "face our history" and reconcile with victims of its Nazi past (McCurry 2015).

However, it would be short-sighted to conclude that Germany did a better job than Japan from the outset. In analysing the different approaches to remembrance culture in the two countries, we use the theoretical framework of civil religion to assess the impact of the respective civil religion on remembrance culture. This concept was introduced by Jean Jacques Rousseau in the late 18th century (Book 4, Chapter 8 of his Contract Social, 1762). Here, he describes what he considered a set of quasi-religious attitudes essential for making a country the object of the citizens' adoration. In this view, civil religion is consciously "designed" by leaders to exert social control over the citizenry (Coleman 1970: especially p. 67; p. 69). This concept was further developed by Robert N. Bellah in his essay Civil religion in America (1967). According to Bellah, who stands in the tradition of Durkheim, civil religion is a common set of fundamental beliefs, values or rituals of a given society. Since it stems from the underlying culture, it develops naturally within a certain society and primarily has an integrative function (Bellah, 1967: p. 4; Christi, 2001: pp. 4 ff.). ${ }^{2}$ Overall, a civil religion can be seen as the mode of citizenship and shared national self-understanding or a nation's national identity. It is a widely accepted fact that national identities are negotiated via discourse that affects the culture of commemoration and vice versa. ${ }^{3}$

Based on these two main theoretical interpretations of civil religion, we seek to asses the importance of history and culture, i.e. the social circumstances (Bellah's sociological approach or 'structure') and to clarify the roles of political leadership and regime change, i.e. individual political action (Rousseau's political approach or 'agency') in framing each country's civil religion and its manifestation in a specific culture of remembrance. We thus presuppose a complementary effect of structural factors and individual agency. ${ }^{4}$

We will address the following subquestions: Concerning the structural aspects, we wish to know about the embededdness of the respective pre-war totalitarian ideologies into traditional cultures, to assess how each civil religion was transformed through the process of democratization and to determine the origins of the post-war order, to investigate into the differences in victim myths and offender consciousness and to highlight the differences in the political environments (integrative European environment vs. a growing China).

Concerning the political and ideological aspects, i.e. the role of the political leaders and their actions, we seek to assess regime change's role in the acceptance of apologies and to investigate into the differences within the two post-war generations concerning collective memory, thus altering concepts of citizenship and national identity and remembrance culture via political protest and generational change. Since the nation-state effectively controls the content of education, we further seek to assess to what extent these differences are shaped by differences in education. Considering that history shapes a civil religion and a remembrance 
culture and that both are altered by the interaction of agents and structures in the matrix of time, we follow a more or less chronological sequence in our analysis.

\section{Civil religion and remembrance culture in Germany}

\section{Civil religion in the Third Reich}

Third Reich ideology was mainly based on ethnic criteria. Specifically, Darwin's On the origins of species by means of natural selection, or the preservation of favoured races in the struggle of life (1859) played a major role in defining Germany as the Herrenvolk (master race). Even though some define Darwin as a scholar of "liberal progressive cast", he was responsible for the theory of natural selection as a mechanism of evolution (Burleigh and Wippermann 2003: p. 28). Houston Stewart Chamberlain was very influential in fusing Social Darwinism with anti-Semitism. ${ }^{5}$ According to this author, the Germans were superior to other races, and this superiority was threatened by the Jews. In Mein Kampf, Hitler proposed that Germanic peoples were the purest of the Aryan race and were therefore the master race. The Chinese and Japanese were seen as "culture bearing races", while others races, such as Blacks or Slavs, were categorized as inferior. The Jews were seen as the embodiment of evil (Burleigh and Wippermann 2003: pp. 36-38). Thus, the Aryan race had to be maintained and improved, and interbreeding with 'less valuable races' would inevitably lead to an extinction of the Aryan race. This anti-Semitism eventually culminated in the Holocaust.

The term Lebensraum (living space) was first used by renowned Leipzig University geographer Friedrich Ratzel (1844 to 1904). Two elements of this concept were crucial: First, Ratzel's emphasis on migration and colonialisation in occupying new space by a certain species; second, the notion that human culture depends directly on land and the methods of agriculture (Smith 1980: pp. 52-54). Lebesraum ideology became a major part of Nazism, referring to Germany's expansion into territories held by the Soviet Union, justified by the need for agricultural land in order to maintain the German nation. In Mein Kampf, Hitler articulated Lebensraum as a kind of natural law, through which the superior Aryan race has the right to displace inferior races in order to achieve new Lebensraum (Lee 2003: p. 237). The politics of Lebensraum explicitly assumed the racial superiority of Germans as the master race that, by virtue of their superiority, had the right to displace any people deemed to be of inferior racial quality (Baranowski 2011: p. 141.).

Another element was the idealisation of tradition and folklore. The Nazis' interest in folklore is addressed in a number of publications. Specifically, Alfred Rosenberg's $^{6}$ Kulturgemeinde issued a flood of literature on Nordic-Germanic literature. Its two major journals were primarily dedicated to Nordic-Germanic symbols, traditional folk art and folklore derived from peasant ancestors. First and foremost, this folklore was the quest for cultural unity of the Volk. Attention was drawn on alien elements in German culture and foreign influences, even humanism, which led to a distinction between the academic upper classes (who could speak Latin, Italian or French) and the common folk (Kamenetsky 1972: pp. 221224). Nordic-Germanic culture was praised as the 'native culture' and soon 
became the basis for German self-identification. It was claimed that the social and religious order of the Nordic-Germanic tribes was the order of the future and that the Roman civilization of the past had serious weakened German folk culture. The Nazis contrasted 'healthy' peasant culture and 'degenerate' city culture by stressing the significance of family bonds, village customs, traditional peasant festivals, folk music, folk dances, processions and so on. According to the Third Reich's Blood-and-Soil Program (Blut und Boden), the peasantry was seen as the Nordic race's life source, even though the peasants' contribution to the Reich was insignificant. However, it remains questionable whether Hitler believed in the folklore policies, since he greatly admired bombastic and monumental city style, reflected in his plans to make Germany's capital, Berlin, as the world capital Germania (Kamenetsky 1972: pp. 227-28, p. 234).

The Nazis wanted to transform the subjective consciousness of the German people into a single-minded, obedient 'national community'. Thus, they wanted to replace class, regional and, specifically, religious allegiances (Kershaw 2000: pp. 173-74). Even though there was some diversity of views among the Nazi leaders as to the future of religion in Germany, Hitler favoured the Protestant religion, and under the Gleichschaltungsprozess, he sought to create a unified Protestant Reich Church (Deutsche Evangelische Kirche) with the goal of eradicating the churches' influence. According to Shirer (1990: p. 240), the new church could not have any priests; Reich orators would address congregations. All crucifixes, pictures of saints and the Bible would be banned. Instead, Mein Kampf, would replace the Bible as the most sacred book. However, owing to strong resistance by the churches, this plan failed.

The Catholic Church was subject to persecution, but in 1933 the Reich signed a Concordat with Rome that pledged respect for the autonomy of churches'. However, the Reich disregarded the Concordat, and all religious institutions that were not strictly religious were closed down. Payne (1996: p. 9.) has argued that fascism basically presupposed a post-Christian, post-religious and secular frame of reference. Thus, it was fundamental to fascism to create a civil religion that would bind the nation together in a new common faith and loyalty.

Although it failed to use the Protestant church as a hub to create a new civil religion (more of an uncivil religion), Mein Kampf became the 'holy book' in this religion; Hitler himself was the highest sacred authority, known as the Führerprinzip (leader principle), which meant that the Führer's word was beyond written law. In the words of Schmitt (1934: p. 38), this provided Hitler with the authority to serve as the "highest form of administrative justice".

Some authors have thought to trace the roots of Nazism deep in the German past and national character, yet, as Stackelberg (2007: p. 24) has argued, those studies unreflectively echo the Nazis own claims of embodying Germany's great cultural traditions. There is no doubt that many of these ideas were already in existence, such as Fichte's renowned addresses to the German Nation, ${ }^{7}$ which became a founding document of German nationalists, or Nietzsche's claim that "God is dead" and his concept of the Übermensch, ${ }^{8}$ yet these ideas were misused by the Nazis and reworked into a very different political and cultural concept. ${ }^{9}$ Despite the Nazis cynical evocation of German cultural traditions, Germany's pre-WWII 
civil religion was consciously designed and invented by Nazi leaders; they used these ideas to create their conception of a fascist society.

\section{Civil religion and remembrance culture and in post-war Germany}

\section{Zero hour in Germany and democratic rebirth}

After fascism and the Holocaust, as the most excessive rupture of civilisation in history, West Germans ${ }^{10}$ resisted patriotism and nationalism. Although many were indoctrinated by Nazi ideology, the crime was too apparent to publicly defend this ideology It is undeniable that many Germans saw themselves as victims. Specifically the suffering of those, who were expelled from their homelands in Eastern Europe let to victimization tendencies and "victim myths". In light of the atrocities committed by Germans during the war, however, there were limits to victim discourses (Stackelberg 2007: p. 49).

Between 1945 and 1949, 13 trials were carried out in Nuernberg (the Nuernberg Trials) to bring Nazi criminals to justice. Although Adolf Hitler and other highranking officials committed suicide and were never brought to trial, Nazi party officials and high-ranking military officers, along with German industrialists, lawyers and doctors, were accused. During the first trial against major war criminals between 1945 and 1946, 12 were sentenced to dead by hanging, one in absentia. Of the 177 people indicted in the subsequent trials, 24 defendants received death sentences and 20 others life in prison, and an additional 98 people received sentences of varying lengths. ${ }^{11}$

In 1948, the three western occupying powers (USA, Great Britain and France) as well as the western neighbours of Germany debated the future of the western occupation zones and agreed on establishing a federal West German state. On 1 September 1948, the Parliamentary Council (Parlamentarischer Rat) was inaugurated to draft the Basic Law for the Federal Republic of Germany (Grundgesetz). Many of its members, specifically those from the Social Democratic Party, had been prosecuted during the time of fascism or had been in exile. ${ }^{12}$ Pressured by the Office of Military Government for Germany (OMGUS), which sought to influence the concrete design of democracy, the council adopted the constitution on 8 May 1949 despite conflicts among the parties concerning the level of decentralization, finance or voting system. ${ }^{13}$ Shortly thereafter, it was approved by the Western Supreme Commanders. However, since the public was excluded from this process, public acceptance and understanding was very low: $40 \%$ had no interest in the new constitution, while only $21 \%$ showed some interest. Until the start of the 1950s, a majority shared the opinion that the totalitarian Nazi regime was based on a good idea that was unfortunately poorly implemented (Noelle and Neumann 1956: p. 134, according to Vorländer 2009). This changed only gradually over the course of time.

In 1949, the main question in Germany was whether to democratize the country and to integrate the mid-level National Socialist (NS) elite or to reappraise history and to punish those guilty of NS crimes. The new political elite chose the first option, since there was a great desire to get rid of all the guilt. Nijhuis (2016: pp. 2-3) called it a "limited political purge", because rigorous de-Nazification would have been detrimental to the reconstruction of Germany and would have made it more difficult to integrate citizens into the new political order. Until the end of the 1950s, no one spoke about 
the Holocaust. The Third Reich was treated as irrelevant (Wolfrun 2008). Due to the emergence of the cold war, the U.S. also lost interest in denazification. In 1951 this process officially ended when the Entnazifizierungsschlussgesetz (law ending the process of denazification) was passed, and many officials were allowed to return to office. ${ }^{14}$

\section{The Cold War, European integration and economic growth}

As a consequence of WWII and the split of Europe into East and West, the European Coal and Steel Community was formed at the start of the 1950s to achieve military security and economic growth and to promote a lasting reconciliation between France and Germany. Some years later, the Treaty of Rome was signed, the cornerstone for the European Economic Community (EEC), the predecessor organisation of the European Union (EU).

Since the Holocaust had made it difficult to develop a new German national identity, or rely on the old identity, economic success filled this gap. The slogan 'Made in Germany' filled West Germans with pride and allowed them to find a positive moment of identification (von Dirke 1997: p. 13). Owing to the intensifying Cold War, Germany was accepted into NATO in 1955, and the ongoing process of European integration was the main instrument for ensuring renewed acceptance from its neighbouring countries. Since Germany renounced any fight for national interests, and pursued and financially supported the process of European integration, it managed to transform itself from a hated country into a respected partner within a very short time. Since Germany had given up on thinking in national terms, Europe became the "Ersatz nation" for the discredited nation-state (Nijhuis 2016: p. 2, p. 6).

At the 10th anniversary of the failed 20 July plot of resistance fighters attempting to kill Hitler, a first memorial service was held, with then President Theodor Heuss (1884 to 1963, President from 1949 to 1959) in attendance. Before this event, only one-third of Germans said that they had a positive opinion about the men who sought to overthrow the Nazi regime. After this speech, public opinion began to shift. Today, 20 July is an integral part of Germany's cultural memory (Dittrich 2014).

Starting with the widely publicized desecration of a synagogue in Cologne on Christmas day 1959, however, a wave of anti-Jewish incidents swept across Germany and other countries (Ehrlich 1962). Until end January 1960, 470 anti-Semitic attacks were reported in West Germany (Bergmann 1990). Awakened by the anti-Semitic events of the winter $1959 / 60$ and in response to other countries' reactions, the first serious activities towards a stronger contemplation of NS history began at the start of the 1960s.

\section{8 and beyond: student protest and regime change as a driving force for assuming responsibility}

The major driving force behind coping with the past was the student protests in the 1960s. The anti-Semitic wave at the end of the 1950s, together with the debate of whether or not the Nazi crimes should be exempted from the statutory 20-year limitation period ${ }^{15}$ in the run-up to the Frankfurt Auschwitz trials 1963-65, led to the student protests, which demanded that Germany deal honestly with its past. To the students, who were not involved in the crimes and were educated in postwar Germany, the German chapter of fascism was not yet closed. Many former National Socialists were still working for the government or at German universities. 
In fact, then-Chancellor Kurt G. Kiesinger (1904 to 1988, Chancellor from 1966 to 1969) had been a member of the Nazi Party. In addition, the newly formed rightwing National Democratic Party (NPD) was attracting more and more voters.

The protests, among other events such as the passing of the German Emergency Law, ${ }^{16}$ were fuelled by the Auschwitz trials, which attracted much publicity in Germany. The first edition of Kursbuch, edited by Hans-Magnus Enzensberger, which soon became the journal of the new left, intensively covered the Auschwitz process. Specifically, Martin Walser's (1965) essay Unser Auschwitz rouses a wide public interest and led to a renewed confrontation with Germany's past. Particularly, the exhibition Ungesühnte Nazijustiz (Unpunished Nazi Justice), which was initiated in different cities by the West Socialist German Student League (Sozialistischer Deutscher Studentenbund, SDS), attracted much attention. The students gathered together wrong judgments from the National Socialist time and made known the responsible judges and prosecutors, specifically those who were still in office (Kraushaar 2008: chapter 3). The students also had a close look at their universities, identifying professors with a Nazi past, demanding their dismissal, which let to severe conflicts within the universities. ${ }^{17}$ The East German regime fuelled this development by publishing details of Nazi collaboration of West German politicians. ${ }^{18}$ The generational conflict in Germany over this time found expression in the popular slogan Die Väter sind die Täter (the fathers are the offenders).

In 1969, regime change took place in Germany. The Social Democrats' Willy Brandt (1913 to 1992, Chancellor from 1969 to 1974), a resistance fighter who had been in exile during the Nazi regime, became Chancellor. When he visited Poland in December 1970, he knelt before the monument of the Warsaw Ghetto Uprising against the Nazi regime. This became known as the Warsaw Genuflection. According to a survey of the time, not all Germans considered the Kniefall was appropriate. Specifically, among the middle-aged generations a majority found it excessive, while among the younger generations, a majority considered it appropriate (Spiegel Umfrage, 1970). Internationally, the reaction was very positive. In 1971, Brandt received the Nobel Peace Prize. In her Award Ceremony Speech, the Nobel Committee's President, Mrs. Aase Lionæs, said:

"Brandt's East European policy is an attempt to bury hatred and seek reconciliation across the mass graves of the war. How important it was for him personally to carry out this task of reconciliation is demonstrated by his kneeling by the Jewish memorial in the former ghetto of Warsaw." ${ }^{19}$

The value change that began with the 1968 student protests and that took place in all advanced industrial nations increased support for democracy, tolerance of foreigners and ethnic minorities and support for gender equality. It changed attitudes towards the environment, religion, work, family, politics, national identity, culture, diversity and subjective well-being, especially among the post-war generation. However, it was pointed out that, in Germany, it manifested itself as a clash between generations, namely the war and the post-war generations. Whilst the war generation preferred materialistic values and an authoritarian regime, the younger post-war generation showed support for post-materialistic values and a libertarian political regime. Kielmansegg (2000: 358) has called Germany the "Republic of two 
generations". ${ }^{20}$ With the dissipation of the war generation, the generational divide also vanished. Thus, some have argued that we are witnessing an end of Germany's unique path of value change and are seeing some kind of "normalization" (van Deth 2001: p. 30).

\section{The Holocaust series and official education}

In 1979, the U.S. TV series Holocaust was aired in Germany, with an estimated viewership with up to 15 million households, leading to an increased public interest into the crimes committed during the Nazi era. After each episode of Holocaust was aired, a panel of historians answered questions from people who phoned in. Many were shocked, stating that they were born after 1945, and that it was the first time they had heard about the genocide. They wanted to know how this could have occurred and why they had never learnt about it at school (Ludtke 1993: pp. 544-46). In 1979, Holocaust became the word of the year.

In the 1980s, it was discussed how the Holocaust could be included into the education curriculum. The subject increasingly formed part of education (Wetzel 2008). Today, it is official policy that a past that is not examined fully and honestly will be a burden to the future. Thus, the subject of the Holocaust is found in every school curriculum in Germany. At different stages, the Holocaust must be covered extensively in history and civic studies, and may also feature in German literature, religion or ethics classes. The Standing Conference of State Education Ministers, a member of Germany's International Holocaust Remembrance Alliance (IHRA) working group, is responsible for curriculum co-ordination. Memorial sites were established. Germany conserves more than 2000 memorial sites that bear witness to the horrors perpetrated by the Nazi regime. Approximately 200 of these are deemed of national importance, including former concentration camps such as Buchenwald, Bergen-Belsen and Oranienburg. Schools are encouraged to organise visits to memorial sites, documentation centres and museums; every year, several hundred thousand students visit these sites. ${ }^{21}$

\section{The 1980s and beyond: constitutional patriotism or 'normal' nation?}

Although much has changed since the immediate post-war period, the Historikerstreit (historians' dispute) started in 1986. The argument was made that the Nazi murders were a defensive reaction to the class murders during Stalinism. Philosopher Jürgen Habermas responded that the authors were trying to whitewash Germany's past and the uniquely crime that was the Holocaust. Habermas further argued that instead of relying on national culture, the Germans should rely on constitutional patriotism, i.e. the values of a pluralistic liberal democratic constitution as a tool of unifying (West) Germany. Constitutional patriotism was a move away from the notion of ethnically homogeneous nation-states. While traditional patriotism consists of a political identity centred around a nation's historical traditions, constitutional patriotism is based on identification with the universalist principles of democracy and human rights, as enshrined in a particular constitution. As a result, a 'post-national' identity emerged. Constitutional patriotism refers to the citizens who feel that they are a nation not because they share a common culture, history or origin, but because they agree on the organizational principles of the state (Habermas 1998). 
The guiding culture (Leitkultur) debate began in the end of the 1990s. The concept was introduced by the German-Arab sociologist Bassam Tibi in his book Europa ohne Identität (Europe without identity) (1998). He defined the values of Germany's constitutional patriotism, namely modernity, democracy, secularism, the Enlightenment, human rights and civil society (p. 39, p. 154), which in his view are also the values of Europe. Tibi did not advocate a German monoculturalism, favouring cultural pluralism based on a value consensus. However, his proposal was altered by German conservatives, who demanded that immigrants should assimilate into a German Leitkultur (Pautz 2010: p. 46). Because the red-green coalition government at the time planned to introduce new laws for immigration and dual citizenship, the debate attracted nationwide attention. In the view of Pautz (2010: p. 41), the Leitkultur debate contributed to the discourse of 'normalisation' that began to take root in the early 1980s. Conservative forces sought to re-establish a 'normal' German consciousness by attacking the 'culture of remembrance'. They sought to re-establish national identity and consciousness within a European context, i.e. the safe realm of a 'European identity' formed by enlightenment and modernity. However, the Leitkultur was heavily criticized by Habermas and others who claimed that the debate was increasing xenophobia among the broader population (e.g. Habermas 2010).

The German 'summer fairy tale' during the 2006 World Coup ushered in a new wave of patriotism and was also seen as a kind of normalisation. The Germans showed themselves to be a people who were easy-going and that could party. The rest of the world took notice of the friendly, open nation that had come a long way since WWII (Seitz 2007). However, while the impacts of the 'summer fairy tale' remain unclear, there is a consensus that the shadows of the past remain and that Germany remains a "difficult fatherland" (Kielmansegg 2000: chapter 4; van Deth 2001: pp. 29 f.); this is also illustrated by the rise of the Euro-sceptic rightwing populist Alternative für Deutschland (AfD).

\section{Civil religion and remembrance culture in Japan}

\section{Civil religion and nation-building in pre-war Japan}

Modern nation-building in Japan started with the Meiji Restoration of 1868. It was carried out by the governing elite to defend Japan from likely colonisation by Western countries, and to improve the unequal treaties with foreign nations. ${ }^{22}$ In its quest for a new national and cultural identity, the Meiji state began to promote indigenous Shintô as a state religion. In 1869, today's Yasukuni Shrine (Yasukuni jinja), which plays a major role in Japan's culture of remembrance, was established under the name Tôkyô Shôkonsha (shrine to summon the souls) in order to honour those who had died for the royalist cause at the time of the Meiji Restoration. In line with Shintô belief, it hosts the souls of the war dead, who are enshrined here as kami (souls or deities).

Soon after the Restoration, the Great Doctrine (Taikyô senpu) was issued. According to this doctrine, the "way of the gods" was declared Japan's government's guiding principle. It became official doctrine that Japan was a God-favoured country and thus superior to all others (see Hardacre 1989: pp. 101-2; pp. 30-3). In contrast to traditional Shintô, in which natural phenomena (e.g. the sun, mountains, trees, or rocks) were worshipped, this newly designed State Shintôism venerated the Emperor. 
Amateratsu (Amaterasu ômikami) - the Sun Goddess - was declared the major deity in the new system of State Shintôism; she is seen as the foremother of the imperial family. Thus, Japan's Emperor, who claimed to be a direct descendant of Amaterasu, was sacred, and all his proclamations had a religious character. Ise shrine, which was dedicated to Amaterasu, was declared Japan's highest-ranking shrine. A system of 13 rites were invented in which the Emperor performed before an audience of state dignitaries (Hardacre 1989: p. 29).

To make Shintôism the only religion in Japan, Buddhism and Christianity were discarded. Upon pressure from the Western powers, the Meiji state shifted to more tolerant religious policies and eventually granted freedom of religion in the Meiji Constitution, which was promulgated in 1889. This constitution stipulated that "the Empire of Japan shall be reigned over and governed by a line of Emperors unbroken for ages eternal" (Art. 1), and that the Emperor had full executive authority and was the supreme commander of the army and the navy (Art. 4, 11). Although the Empire of Japan is the oldest hereditary monarchy in the world, Takayama (1993: p. 107) argues that State Shintôism was a newly designed religion to ideologically control Japan's people.

From the 1880s on, Japan's government increasingly used education to teach nationalist ideas. Through a nationalist education, the Meiji government sought to strengthen national and social unity. In 1890, it issued the Imperial Rescript on Education (Kyôiku chokugo), requiring students to ritually recite the oath to "offer yourselves courageously to the State" as well as protect the imperial family. The basis of the Rescript was that Japan's unique form of government, the kokutai, was based on a historic bond between benevolent rulers and loyal subjects, and that the fundamental purpose of education was to cultivate virtues, especially "loyalty" and "filial piety". ${ }^{23}$ The practice of emperor worship was further spread by veneration of the imperial portrait. All these practices were used to fortify national solidarity and gave pre-war Japanese nationalism a tint of mysticism and cultural introversion (Hall: 1994, p. 321).

In the early 20th century, Japan grew into a major industrial-military power. Japan saw its future in industrialisation and expansion but, being an island, it didn't have the resources to support this, so the Japanese sought to secure resources via invasion. Disputes over Korea and Manchuria led to the first Sino-Japanese War with China (Nisshin sensô) in 1894-95 and the Russo-Japanese War (Nichiro sensô) with Russia in 1904-05. The victories of the Japanese surprised the world and left Japan with a sphere of influence extending over southern Manchuria and Korea.

Since the government and the economy needed new resources, this opened the way for further Japanese expansionism. The government and the army repeatedly supported imperialistically motivated aggression, as did large Japanese companies looking for new resources, opening the way for the ascendancy of military supremacy in politics. State Shintô provided a mythical justification for colonialism and the actions of the Japanese military in the years leading up to WWII and Japan's defeat. Since Amaterasu was promoted the most important of the gods and was given a national role, the sovereignty of the Emperor as her direct descendant was secured by divine right. Further, it became official doctrine that, since Japan was a God-favoured country, the Japanese were superior to all other races. ${ }^{24}$ Until the end of WWII, Japan's government used this "invented tradition" of State Shintôism 
as a unifying ideology centred on a sacred Emperor to mobilise the people for nation-building, modernisation and, eventually, military expansionism and colonialism (Mullins 1993: p. 76).

The Manchurian Incident in 1931 marked the start of the Second Sino-Japanese War, although full-scale war would not start until 1937. According to Hobsbawm, the incident was a milestone on the road to WWII (Hobsbawm 1994: p. 37).

On June 29, 1940, the concept of the Greater East Asia Co-Prosperity Sphere (Daitôa kyôeiken) was announced via a radio address. It declared the will to establish a new order in Asia, free from Western influence (De Bary 2008: p. 622). Soon thereafter the Japanese launched their mission to bring Southeast Asia under their control and from 1942 onwards the Japanese controlled nearly all of East and Southeast Asia, which provoked strong resistance among these nations. By the year 1945 anti-Japanese resistance movements had emerged nearly everywhere in Asia. ${ }^{25}$

\section{Civil religion and remembrance culture post-war Japan}

\section{Zero hour in Japan: continuity and change}

Shortly before the war's end, Japan was bombed to ashes. Tôkyô was severely damaged, as were other parts of Japan. On 26 July 1945, the Potsdam Declaration was issued in the form of an ultimatum to hasten Japan's surrender, without guaranteeing the status of the Emperor, Japan's most important condition to capitulate (Bix 2001: pp. 496-504). Because Japan had said it intends to "ignore" (mokusatsu) the Declaration, the Allies dropped nuclear weapons on Hiroshima and Nagasaki, which killed thousands of people, also in the aftermath, many of whom were civilians, mostly women and children. On August 15, 1945, Emperor Hirohito stated in his Imperial Rescript on the Termination of War (gyokuon hôsô) that against the background of the dropping of the atomic bomb a continuation of the fight would not only lead to an ultimate collapse of the Japanese nation but also to the total extinction of human civilization. It was not surprising that he did not mention any Japanese aggression, instead he expressed his deepest regret to 'our allied nations of East Asia' who cooperated with Japan to liberate Asia from Western colonization. ${ }^{26}$ Tanaka (2013) has argued that the Rescript instilled in the people the myth that Japan was forced to surrender by the inhumane atomic bomb and thus cultivated an exclusive victim mentality. Powerful experiences of the bombings were written during the occupation period, some suppressed by U.S. censorship, and the Japan as victim myth began to snowball - a significant difference to the case of Germany. ${ }^{27}$ In 1947, peace groups held the first Hiroshima Memorial Day, which has since been held every year (Newman 1995: p. 158).

After the country's defeat in WWII, Japan's political system underwent radical changes under pressure from the Allied Powers, especially the U.S. In September 1945, General Douglas McArthur took charge of the Supreme Command of Allied Powers (SCAP). Even though the other Allies had an advisory role, the SCAP had the final authority to make decisions in Japan. As in Germany, a primary objective of the occupation forces, namely the U.S., was to punish war criminals. The General Headquarters (GHQ) carried out a far-ranging purge and prohibited persons who were active exponents of militarism and militant nationalism from engaging in public service. In May 
1946, the Tôkyô Trials began. The allied criminal trials indicted 25 people as Class A war criminals, and several thousand as Class B or Class C war criminals. Six defendants were sentenced to death by hanging for war crimes, crimes against humanity, and crimes against peace, including former Prime Minister Tôjô Hideki (1884 to 1948, Prime Minister 1941 to 1944). Some preferred to die by their own hand. ${ }^{28}$

Concerning the new political structure, we find a major difference between Japan and Germany: While the Germans wrote a new constitution by themselves, the Japanese presented only minor changes of the Meiji Constitution. This can be attributed to the fact that in Japan the draft was produced by the government under the supervision of the then Minister of State and pre-war Minister of Commerce and Industry, Matsumoto Jôji (1877-1954), while in Germany politicians who had been in opposition to the NS-regime negotiated the statutory stipulations. The GHQ rejected the Japanese draft outright and ordered its staff to write a completely new document, which was presented to the government in early 1946 (Bix 2001: pp. 568-579). In this constitution, the Emperor's role was reduced to that of a "symbol of the state" (Art. 1) and in 1947 the Emperor had to issue the "Humanity Declaration" (Ningen sengen), in which he had to deny all claims to be a living god. It also contained Article 9, the Peace Article of the Constitution, which prohibits Japan from ever leading a war again or from maintaining an army. Since the constitution was of foreign origin, it was a source of controversy from the outset, specifically concerning the Emperor's role and Article 9. Besides, Shintô and the state were clearly separated, and Yasukuni Shrine too was made independent from the state, and has since been privately funded.

\section{The Cold War, 'reverse course' and the stabilising of conservative domination}

The Cold War led to the Allied Occupation's 'reverse course'. After the promulgation of the both Korean states and the communist takeover in Beijing, the GHQ ordered the Japanese government to purge all Communist party officials from office - known as the Red Purge (reddo pâji). Thousands of workers, trade unionists and public servants were dismissed. At the same time, suspected Class A war criminals were released from prison. ${ }^{29}$

The goal of supporting Japan against China and North Korea also led to the founding of the Self Defence Forces (SDF) (Jieitai), which was prevention from the democratic ideals of the constitution and enabled the established conservative elite to fortify their ruling position (Kingston 2010: 13-4). In 1952, the San Francisco Peace Treaty was signed, which ended the occupation period, and Japan regained full authority.

As was true for Germany, Japan profited greatly from the Cold War. The Korean War, which broke out in 1950, resulted in the swift recovery of Japan's economy. The rapid economic growth during the 1960s - known as the 'economic miracle' - rapidly increased standards of living and gave rise to a new middle class. This new middle class was greatly interested in stability, which led to a consolidation of the ruling position of the conservative Liberal Democratic Party (LDP) (Jiyû minshu tô). ${ }^{30}$

\section{Student protests and textbook discourse}

Student protests in Japan were highly visible in the early post-war period. They included a defence of the earlier, democratising and de-militarising reforms of the Allied Occupation as well as the defence of the Peace Constitution, especially Article 9, 
opposition to feudal practices in politics, economy and social life, the defence of workers' interests against monopoly capital, and opposition to so-called 'U.S. imperialism', which was at odds with defending the U.S.'s post-war democratic reforms (Stockwin 2003: p. 232).

This position greatly resembled the major conflict lines in Japanese politics during these times, namely between capital and labour and between a traditional and a modern value orientation. While the LDP organised the rural, lower-educated older generation, the leftist parties, the Japanese Socialist Party (JSP) (Nihon shakai tô) and the Communist Party (JCP) (Nihon kyôsan tô) organised the urban, better-educated younger generation (Schmidt 2001). Both leftist parties tried to take over control of the student movement, yet it established themselves as more or less politically independent. The forming of the SDF in the 1950s and the revision of the Japan-US Security Treaty in 1960 provoked mass demonstrations against the Eisenhower visit. Also, the then Prime Minister, Kishi (1896 to 1987, Prime Minister 1957 to 1960), a former Class A war suspect and grandfather of current Prime Minister Abe Shinzô (born 1954, Prime Minister 2006 to 2007, 2012-), who returned to political life after the 'reverse course', was forced out of office. However, in the immediate aftermath of the crisis, the students returned to their hometowns and villages. The Vietnam War provoked new student protests in 1968 against 'U.S. imperialism'. Specifically at Japan's leading university, the University of Tôkyô, the situation became so serious that the university closed for several months. After the early 1970s, the universities swiftly returned to normal; by the 1980s, observers were stunned by the students' conservatism (rather than radicalism) (Stockwin 2003. p. 233).

From the outset, Japan's government has effectively controlled the content of the history textbooks used in secondary education. Some international observers perceive this control to be Japanese nationalist efforts to whitewash the actions of the Empire of Japan during WWII, and see it as an attempt to tone down or delete descriptions of Japan's wartime aggression, especially atrocities such as the Nanjing Massacre. In 1965, Saburo Ienaga, a prominent historian, filed the first of his three lawsuits against the Ministry of Education, charging that the textbook approval process was unconstitutional and illegal. His lawsuits lasted 30 years. In 1997, Japan's Supreme Court unanimously upheld the Ministry's right to continue screening textbooks. ${ }^{31}$

\section{Japan as number one: Shintô gods and economic growth}

By the 1970s, the Japanese were living in one of the world's most rapidly growing economies. Japan's political and bureaucratic elite largely guided economic development via extensive regulation and planning. Books such as Ezra Vogel's Japan as number one: Lessons for America appeared and became bestsellers in Japan and the West. Writings on issues of Japanese national and cultural identity are subsumed under the term nihonjinron, literally theories on or discussions of the Japanese (Sugimoto 2003: p. 4). It was argued that Japanese social relations are the core of Japan's economic success (e.g. Nakane 1970). These forms of social relations were seen as being "uniquely unique" to Japan and as providing the country with a unique advantage in building an advanced industrial society (Sugimoto 2003: p. 15).

On 15 August 1975, the 30-year anniversary of Japan's surrender in WWII, Prime Minister Miki Takeo (1907 to 1988, Prime Minister 1974 to 1976) visited Yasukuni 
Shrine - the first post-war visit by a prime minister, even though he insisted he had visited as an individual and not as prime minister. On 9 April 1979, surprisingly, it was announced that the most prominent 14. Class A war criminals had been enshrined at Yasukuni Shrine on 17 October 1978, along with 2,450,000 other war dead (Takayama 1988: pp. 331 ff.). Since then, official politicians' visits to the shrine constitute a major ritual in Japan's culture of remembrance and show the alignment between Shintôism and the conservative elite.

Another important factor is the various Yasukuni supporter groups, amongst them the Izokukai, (Japan War-Bereaved Families Association), the main organization for families of war dead in Japan. The organization has strong links to the LDP, because their chairmen used to be well-known LDP politicians, like Okinori Kaya (1889-1977), who led the organization between 1962 and 1977. Kaya, who was Minister of Finance from 1941 to 44 , was sentenced to 20 years imprisonment as a Class A war criminal by the Allied occupation. However, he was paroled in 1955 and later served as LDP Minister of Justice. ${ }^{32}$

The relationship between the economy and the Shintô religion was equally important. Most shops in Japan have a small shrine on their premises. Large enterprises revere a local deity of the place where the company was founded. (Swyngedouw 1993: pp. $57 \mathrm{ff}$.). Since numerous festivals are held at these shrines, and the employees are expected to participate, religious rites have survived and may even have increased in both number and variety rather than declining in an industrial urban context. Owing to this religious connection, the companies were deified and became omnipotent in the lives of their employees (Lewis 1993: p. 166, p. 170).. ${ }^{33}$ While in pre-war Japan, Shintôism was used to mobilise people for nationalist goals, it was now used to mobilise people for economic success. This success has further stabilised the LDP's longterm ruling position. At the start of the 1980s, Japan entered a neo-traditionalist period that stressed the 'roots' of Japanese society, and the media played a major role in the production and marketing of tradition (Buckley 1993: p. 368).

The then Prime Minister, Nakasone Yasuhiro (born 1918, Prime Minister 1982 to 1987), was the first to visit the Yasukuni Shrine in an official capacity. He made the visit along with his cabinet on 15 August 1985 (Takayama 1988: p. 335). Others followed, which has led to severe criticism from China and South Korea, the main victims of Japan's aggression during WWII, who consider the shrine to be a glorification of Japan's past military aggression.

\section{The end of economic growth and a regime change}

At the start of the 1990s, Japan's economy slowed markedly. With the burst of the 'bubble economy', an asset price bubble collapse, the economic miracle came to a sudden end. The 1990s were called the "lost decade"; recently, however, the decade from 2001 to 2010 is often included, with the period referred to as the "two lost decades" ${ }^{34}$

With the end of economic growth, Japan's political system fell into turmoil. The loss of political control and planning at the nation-state level had severe political consequences. At the start of the 1990s, Japan's long-ruling LDP was forced into a coalition government with Japan's Social Democrats, and Murayama Tomi'ichi (born 1924, Prime Minister 1994 to 1996) became Japan's first non-conservative Prime Minister after the formation of the party system in 1955. On 15 August 1995, the 50th anniversary of the end of WWII, Murayama apologised (in the "Murayama Statement" (Murayama 
danwa)). This was the first-ever official apology for Japan's war of aggression and the suffering Japan had inflicted on its Asian neighbours. However, regime change formed a short episode. Japan's party system became very fluid, and there was a permanent restructuring of the opposition camp, which benefited the LDP. In the "historical" election of 2009, the opposition Democratic Party of Japan (DPJ), which was formed at the end of the 1990s, won, ousting the LDP from power after more than 50 years of conservative rule. The 2011 triple catastrophe - when the strongest earthquake ever shook Japan, followed by a strong tsunami, and the shameful handling of the Fukushima nuclear accident following the earthquake and the tsunami - led to the end of DPJ government. This sequence of events brought the LDP back to power. Under the guidance of Prime Minister Abe, it is going "back to the roots", as a solution to the current problems (Schmidt 2001, 2011, 2012).

Already in the 1980s, Takayama (1988: p. 118) argued that the move towards a revitalisation of Japanese civil religion would inevitably mean the emergence of other related issues, such as a reversal of those parts of the Constitution that refer to the Emperor's symbolic status, a revision of the Peace Article, or the restoration of traditional 'moral education'. This is also true for the current situation, illustrated by the present discussion about revising Article 9 and an expanded role for Japan's SDF forces. Concerning these discussions, the Japanese public has been deeply divided from the start. Polls show that the percentage of those in favour of a constitutional revision shrunk from $41 \%$ in 2007 to $28 \%$ in 2015, while the percentage of those who oppose revision has been relatively stable at $25 \%$ in 2015 (NHK 2015).

In December 2013, the current Prime Minister Abe visited the Yasukuni Shrine. In February 2015, he said: "It is natural for the nation's leaders to want to visit Yasukuni Shrine to pay their respects to those who died for the country". ${ }^{35}$ Even though Abe did not visit the shrine at Yasukuni's annual Spring Festival in 2015 so as to avoid diplomatic embarrassment, sending a ritual offering instead, 106 lawmakers from both the government and the opposition visited the shrine, including three cabinet ministers, which again infuriated South Korea and China. ${ }^{36}$ On 15 August 2015, the 70th anniversary of the end of WWII, Abe again decided not to visit owing to diplomatic tensions; however, despite severe criticism from China and South Korea, 60 politicians (including several ministers) visited the shrine. ${ }^{37}$

The issue also frequently leads to domestic dispute, and Japan's public is deeply divided on this topic. In January 2014, for instance, $41 \%$ of respondents in an Asahi Shinbun poll had no problem with Abes's visit to Yasukuni, while $46 \%$ said he should not have visited. ${ }^{38}$

Several proposals have been made to create a separate secular memorial where the prime minister can make official state visits for memorial purposes; however, such proposals are often blocked by the conservative elite and organizations like the Izokukai. ${ }^{39}$ Therefore, the shrine remains a subject of political debate in Japan and an obstacle to meaningful relationships between Japan and its neighbours.

Further, in early 2014 the Abe government has issued new guidelines that ensure that the history textbooks used in schools from 2017 onwards reflect the government's positions on territorial issues such as the disputed islands between Japan and its neighbouring countries. These islands matter because of nearby shipping lines, fish grounds and potential oil and gas fields. Further they are of military importance 
because of their strategically significant position. For the first time, the textbooks will refer to the Senkaku Islands/Diaoyu (controlled by Japan and disputed with China) and Takeshima/Dokdo (controlled by and disputed with South Korea) as "Japanese territory", which most likely will lead to a further worsening of Japan's relations with the neighbouring countries. ${ }^{40}$

\section{Conclusions}

Civil religion and remembrance culture are closely interrelated. Besides analysing civil religion in (West) Germany and Japan in pre-war and post-war times, we sought to highlight the differences and similarities of two civil religions and remembrance cultures in a comparative perspective. We hereby analyzed the structural factors as well as the influence of individual political behaviour, i.e. the interaction of 'structure' and 'agency' in shaping the respective civil religion and remembrance culture. Table 1 summarizes the findings.

Both Germany and Japan were occupied by the Western Allies, and both integrated large numbers of those responsible for war and war crimes into their society rather than punishing them. Immediately after the war, neither the Germans nor the Japanese were interested in coming to terms with their past. Both countries were subject to Western integration, and both faced unprecedented economic growth. One of the major differences between the two countries is their civil religions. The ethnicity-based Nazi civil religion was consciously invented and designed by its leaders without any deep cultural rooting in German society. Thus, it was easier to abandon an inappropriate past. After the war, Germany no longer relied on strong nationalism-based politics. Instead, it pursued European integration. Likewise, in Japan, State Shintô was invented by the Meiji leaders' however, in its apolitical form, it had long been a source of culture, which is why it continues to influence perceptions of national identity and why it has been more difficult to establish a critical dialogue with Japan's past. Concerning the sources of national pride, there was no clear break with the past in Japan; instead, links were forged between pre-war Shintôism and tradition. Official visits to the Yasukuni shrine by high-ranking politicians highlight the links between Japan's political system and Shintô tradition, which often provokes criticism form China and South Korea. Thus, the pre-war totalitarian ideology in Japan was more embedded in the traditional

Table 1 Summary of differences and similarities of civil religion and remembrance culture in Germany and Japan

\begin{tabular}{|c|c|c|c|c|}
\hline \multicolumn{3}{|c|}{ Factors shaping civil religion and remembrance culture } & \multirow{2}{*}{$\frac{\text { Germany }}{\text { superfluous }}$} & \multirow{2}{*}{$\begin{array}{l}\text { Japan } \\
\text { embedded }\end{array}$} \\
\hline $\begin{array}{l}\text { Structure } \\
\text { (socioolocical factors) }\end{array}$ & 1 & $\begin{array}{l}\text { Embededdness of totalitarian } \\
\text { ideologies in traditional culture }\end{array}$ & & \\
\hline & 2 & Collective experience & Holocaust/guilt & Nuclear bombings \\
\hline & 3 & Origins of post-war order & endogenous & exogenous \\
\hline & 4 & International environment & European integration & Communist threat \\
\hline \multirow[t]{3}{*}{$\begin{array}{l}\text { Agency } \\
\text { (political factors) }\end{array}$} & 5 & Impact of protest movement & $\begin{array}{l}\text { High impact } \\
\text { (68er generation) }\end{array}$ & No impact \\
\hline & 6 & Regime change & $\begin{array}{l}\text { Social-liberal } \\
\text { coalition }\end{array}$ & LDP one-party dominant rule \\
\hline & 7 & Control of education & $\begin{array}{l}\text { Holocaust included } \\
\text { into curriculum }\end{array}$ & $\begin{array}{l}\text { Control of textbooks, esp. } \\
\text { with regard to war crimes }\end{array}$ \\
\hline
\end{tabular}


culture, than in Germany, where the relationship can be described as more extraneous or superfluous.

In Germany, the severity of guilt prevented Germans from defending Nazi ideology in public or to return to nationalism. In Japan, conversely, the bombing of Hiroshima and Nagasaki led to victim myths and the consciousness of being a victim rather than perpetrator. There is another difference: Since Japan's constitution was of Western origin, or exogenous, it was and remains subject of political conflict: While the conservative elite intends to revise parts related to defence and the Emperor's role, the leftist opposition strongly defends these articles. This fact undermines strong constitutional patriotism in Japan as well as pride in its democratic laws, as has been the case in Germany, where the origins of the post-war order can be described as more endogenous, since it was designed by the Germans themselves.

While Germany has benefited from Western - specifically European - integration, Japan was confronted with a conflicting communist environment concerning China and North Korea. Japan took pride in its economic growth, linking it to the Japanese nation and Japanese values and traditions, as well as Japanese uniqueness in Asia and superiority in the world. Since the government has effectively controlled textbooks concerning its past, this has contributed to an undigested historical past.

Although Germans, most of whom were linked to the Nazi regime, also sought to forget about the past rather than cope with it, the 1968 student generation strongly condemned Nazi aggression and demanded that the 'father' generation take responsibility, contributing to a public reappraisal of the past. Since then, public opinion has shifted greatly towards accepting responsibility for what happened, and from authoritarian to libertarian values. This process, together with the airing of the Holocaust series, have largely contributed to the fact that the past has been included in the school curriculum. In Japan, the student protests were fairly visible, but dispersed suddenly and had no further impacts on dealing with the past.

Regime change in Germany has also played a key role. The historic gesture of kneeling before the monument of victims of the Warsaw uprising by SPD chancellor Brand, who had been in exile during the Nazi regime, has highly contributed to reconciliation with then communist Poland. In Japan, economic growth and the necessity of U.S.-Japanese alignment in a critical environment has stabilised one-party dominant rule by the conservatives, who have been reluctant to come to terms with the past. This only occurred in 1995, when the Socialists were in a coalition government and the then Prime Minister, Murayama, first took full responsibility for the past, half a century later than in Germany.

For Germany, European integration, a resistance to nationalism and generational change led to a specific form of Vergangenheitsbewältigung and the crimes of the Holocaust are subject of all school curricula. However, normalisation discourses, the financial and economic crises, the refugee crisis and a weak political union have recently reinforced claims for more national interest, specifically from the populist right. In Japan, the conflicting environment has fostered close Japan-U.S. alignment instead of encouraging Asian reconciliation. Long conservative rule and unprecedented economic growth has encouraged national pride in Japan's unique position in Asia and has led to a re-emergence of traditions rather than encouraging a process of coming to terms with Japan's past. While the sudden end to the 'economic miracle' has led to political turmoil and regime change, the LDP is back in power, and the revision of the constitution and the SDF are back on the political agenda which 
would render any kind of Asian union, or at least improved relationships with China and South Korea, unlikely. The new move of the conservative elite to include the government's position on territorial disputes into the official school textbooks is also more likely to lead to a considerable worsening of the diplomatic relations.

\section{Endnotes}

${ }^{1}$ Comfort women hereby refers to women, especially in Korea, who were compelled into sexual servitude for the nation's wartime forces. The issue has been a constant source of controversy since the early 1990s, when the media started to address it seriously. However, in December 2015, Japan and Korea agreed to settle the issue of comfort women in their first such deal since 1965. Japan has apologised and will pay 1 billion yen to fund victims, even though only 46 former comfort women are still alive in South Korea. For instance, see BBC News (2015).

${ }^{2}$ For the term, see also Schmidt 2015.

${ }^{3}$ The relationship is a two-way one, since there is also a close relationship between historical memory and rituals of commemoration in creating national identity. See e.g. Isakhan 2011.

${ }^{4}$ For the debate on structure and agency as complementary forces see Bourdieu 1977 or Hurrlemann 1988.

${ }^{5} 1855$ to 1927; the son in law of German composer Richard Wagner. His two-volume book Die Grundlagen des neunzehnten Jahrhunderts claimed to prove the superiority of the Aryan race.

${ }^{6} 1883$ to 1946 . Influential ideologue of the Nazi Party. Sentenced to death by hanging during the Nuremberg trials.

${ }^{7} 1782$ to 1814 . The English version can be found at http://germanhistorydocs.ghidc.org/pdf/eng/12_enlightphilos_doc.8_english.pdf. Accessed 2 June 2016.

${ }^{8} 1844$ to 1900 . Both concepts occur in several of his works, notably in Also sprach Zarathustra, published between 1883 and 1891.

${ }^{9}$ Pearson (1994: pp. 33-34) for instance views the description of Nietzsche's political thought as fascist, or Nazi ideology as "absurd". See also Kaufmann 1942.

${ }^{10}$ Until the reunification in 1990, the analysis is limited to West Germany.

${ }^{11}$ As for the trials, see www.kriegsverbrecherprozesse.nuernberg.de

${ }^{12}$ For the biographies of its members see: www.bpb.de/geschichte/deutschegeschichte/grundgesetz-und-parlamentarischer-rat/39043/biografien

${ }^{13}$ For the role of OMGUS and the political disputes between the parties and the various occupation forces see Hahn 1993; Feldkamp 1998.

${ }^{14}$ See Gesetz zur Regelung der Rechtsverhältnisse der unter Artikel 131 des Grundge setzes fallenden Personen 1951.

${ }^{15}$ After several extensions of the deadline, Germany's Parliament suspended the limitation period for crimes against humanity in 1979.

${ }^{16}$ When the grand coalition with Chancellor Kiesinger passed the German Emergency Law (Notstandsgesetze) on 30 May 1968, students heavily opposed it, arguing it was similar to Hitler's Ermächtigungsgesetz (Enabling Act).

${ }^{17}$ See for instance the documentation on Braune Universität. Deutsche Hochschullehrer gestern und heute, edited by Rolf Seeliger et al. Volume 1-6, 1965-68. 
${ }^{18}$ See Nationalrat der Nationalen Front des Demokratischen Deutschland/Dokumentationszentrum der staatlichen Archivverwaltung der DDR 1965.

${ }^{19}$ See Award Ceremony Speech 1971.

${ }^{20}$ For the value change, see also Inglehart 1977 and Kitschelt 1995.

${ }^{21}$ See the Holocaust Remembrance Alliance w. y. Germany.

${ }^{22}$ Like other Asian nations, the Japanese were forced to sign unequal treaties with Western powers. These granted Westerners one-sided economic and legal advantages in Japan. The first of a set of treaties was signed in Kanagawa between Japan and the U.S. (Kanagawa jôyaku) in 1854. For an overview of the treaties, see Auslin 2004.

${ }^{23}$ For the full text of the Rescript, see Tsunoda et al. 1964: pp. 139-140. However, many observers noted that the Rescript was of Confucian origin, especially concerning human hierarchies, which established a sound basis of proper relationships among people.

${ }^{24}$ Bellah (1967) has argued that the U.S. civil religion, the "American Way of Life" or "American Shintô", is a comparable concept.

${ }^{25}$ For this concept see Lebra 1975.

${ }^{26}$ For the full text see De Barry 2008: pp. 624-25.

${ }^{27}$ Another factor was the establishment of the Atomic Bomb Casualty Commission $(A B C C)$ by the U.S. to investigate into the effects of radiation. Since this commission did not provide any medical care to the victims, it intensified feelings of being a victim.

${ }^{28}$ For the tribunal, see International Tribunal for the Far East 1948.

${ }^{29}$ For details, see Takemae 2002: p. 482.

${ }^{30}$ For details, see the various keywords in Schmidt 2003.

${ }^{31}$ For the textbook controversy, see Nozaki 2008.

${ }^{32}$ See: Nihon Izokukai. Homepage.

${ }^{33}$ Even though the participants take part only out of obligation to the company, because it is part of their job (ibid.).

${ }^{34}$ The country's GDP fell, as did real wages, and Japan's economic growth came to a sudden end. In 2011, China overtook Japan as the world's second-largest economy. See BBC News 2011.

${ }^{35}$ See Japan Times 2015b.

${ }^{36}$ Japan Times 2015c. The visits came one day after Prime Minister Abe had held his first substantial talks with China's President Xi Jinping on the sidelines of a summit in Jakarta.

${ }^{37}$ See Japan Times 2015a, and Yahoo News 2015.

${ }^{38}$ See Asahi Shinbun 2014.

${ }^{39}$ For an overview of this topic, see Mochizuki 2010.

${ }^{40}$ See Japan Times 2016. For the territorial disputes see e.g. Drifte 2005.

\section{Abbreviations}

AfD: Alternative für Deutschland (Alternative for Germany); DPJ: Democratic Party of Japan; EEC: European Economic Community; EU: European Union; GHQ: General Headquarters; IHRA: International Holocaust Remembrance Alliance; JCP: Japan Communist Party; JSP: Japan Socialist Party; LDP: Liberal Democratic Party; NPD: Nationaldemokratische Partei Deutschlands (National Democratic Party of Germany); NS: National Socialist; SDF: Self Defence Forces; SDS: Sozialistischer Deutscher Studentenbund (West Socialist German Student League); WWII: World War II 


\section{Competing interests}

The author declares that she has no competing interests.

Received: 9 July 2016 Accepted: 26 August 2016

Published online: 12 October 2016

\section{References}

Asahi Shinbun. 2014. http://www.japanbullet.com/news/46-of-voters-oppose-prime-minister-s-visit-to-yasukuni. Accessed 1 August 2015

Auslin, Michael R. 2004. Negotiating with Imperialism: The Unequal Treaties and the Culture of Japanese Diplomacy. London and Cambridge: Harvard University Press.

Award Ceremony Speech. 1971. Excerpt from the Prize Award Ceremony and Banquet in Oslo ". http://www.nobelprize. org/nobel_prizes/peace/laureates/1971/press.html. Accessed 12 April 2016.

Baranowski, Shelley. 2011. Nazi Empire: German Colonialism and Imperialism from Bismarck to Hitler. Cambridge: Cambridge University Press.

BBC News. 2015. http://www.bbc.com/news/world-asia-35188135. Accessed 15 April 2016.

BBC News. 2011. China Overtakes Japan as the world's second-largest economy. http://www.bbc.com/news/business12427321. Accessed 15 April 2016.

Bellah, Robert N. 1967. Civil Religion in America. Dædalus 96: 1-21.

Bergmann, Werner. 1990. Antisemitismus als politisches Ereignis: Die antisemitische Welle im Winter 1959/1960". In Antisemitismus in der politischen Kultur nach 1945, ed. Werner Bergmann, 253-275. Wiesbaden: Springer VS.

Bix, Herbert B. 2001. Hirohito and the Making of Modern Japan. New York: Harper Collins.

Bourdieu, Pierre. 1977. Outline of a Theory of Practice. London: Cambridge University Press.

Buckley, Sandra. 1993. Altered States: The Body Politics of 'Being-Woman'. In Postwar Japan as History, ed. Andrew W. Gordon, 347-372. Berkeley, Los Angeles, London: University of California Press.

Burleigh, Michael, and Wolfgang Wippermann. 2003. The Racial State Germany 1933-45. Cambridge: Cambridge University Press.

Christi, Marcela. 2001. From Civil to Political Religion: The Intersection of Culture, Religion and Politics. Waterloo, Ontario: Wilfred Laurier University Press.

Coleman, John A. 1970. Civil Religion. Sociological Analysis 31: 67-77.

Gesetz zur Regelung der Rechtsverhältnisse der unter Artikel 131 des Grundgesetzes fallenden Personen 1951. 1965. http://www.bgbl.de/xaver/bgbl/start.xav?startbk=Bundesanzeiger_BGBI\&jumpTo=bgbl165s1685.pdf\#_bgbl_ \%2F\%2F*[\%40attr_id\%3D\%27bgbl165s1685.pdf\%27]_1471777027071. Accessed 12 August 2016.

Darwin, Charles. 1859. On the origins of species by means of natural selection, or the preservation of favoured races in the struggle of life. London: John Murray.

De Bary, William Theodore. 2008. Sources of East Asian Tradition. Vol. 2: The Modern Period. New York: Columbia University Press.

Dittrich, Monika. 2014. How traitors became heroes. Deutsche Welle, ed. http://www.dw.com/en/how-traitors-becameheroes/a-17796469. Accessed 18 April 2016

Drifte, Reinhard. 2005. Japan's Security Relations with China since 1989. From balancing to bandwagoning? London and New York: Routledge.

Ehrlich, Howard J. 1962. The Swastika Epidemic of 1959-1960: Anti-Semitism and Community Characteristics". Social Problems 9(3): 264-272.

Feldkamp, Michael. 1998. Der Parlamentarische Rat 1948-49. Die Entstehung des Grundgesetzes. Göttingen: Vandenhoeck \& Ruprecht. Habermas, Jürgen. 1998. Die postnationale Konstellation. Politische Essays. Frankfurt: Suhrkamp.

Habermas, Jürgen. 2010. "Leadership and Leitkultur". New York Times (28 Oct. 2010). http://www.nytimes.com/2010/10/29/opinion/29Habermas.html?pagewanted=1\&_r=0. Acessed 23 January 2016.

Hahn, Erich J. 1993. US-Policy on a West-German Constitution, 1947-49. In American Policy and the Reconstruction of West-Germany, 1945-1955, ed. Jeffry M. Diefendorf, Axel Frohn, and Hermann-Josef Rupieper, 21-44. Cambridge: Cambridge University Press.

Hall, John W. 1994. Das japanische Kaiserreich. Frankfurt a.M.: Fischer.

Hardacre, Helen. 1989. Shintô and the State 1868-1988. Princeton: Princeton University Press.

Hobsbawm, Eric. 1994. Age of Extremes: The Short Twentieth Century, 1914-1991. London: Michael Joseph.

Holocaust Remembrance Alliance w. y. Germany. https://www.holocaustremembrance.com/member-countries/ holocaust-education-remembrance-and-research-germany. Accessed 12 May 2016.

Hurrlemann, Klaus. 1988. Social Structure and Personality Development. New York: Cambridge University Press.

Inglehart, Ronald. 1977. The Silent Revolution: Changing Values and Political Styles among Western Publics. Princeton: Princeton University Press.

International Tribunal for the Far East. 1948. Judgement. http://www.ibiblio.org/hyperwar/PTO/IMTFE/index.html. Accessed 17 April 2016.

Isakhan, Bejamin. 2011. Targeting the Symbolic Dimension of Baathist Iraq: Cultural Destruction, Historical Memory and National Idendity. Middle East Journal of Culture and Communication 4(3): 257-281.

Japan Times. 2016. http://www.japantimes.co.jp/news/2016/03/18/national/textbooks-add-pages-disputed-territories2017/\#.V6hmtpMvscM. Accessed 5 August 2016.

Japan Times. 2015a. http://www.japantimes.co.jp/news/2015/08/15/national/emperor-voices-deep-remorse-war-70thanniversary-surrender-diet-trio-visit-yasukuni/\#.Vc8wtpN9khd. Accessed 15 August 2015.

Japan Times. 2015b. http://www.japantimes.co.jp/news/2015/02/18/national/politics-diplomacy/its-natural-for-leadersto-visit-yasukuni-abe-says/\#.VcSWW5N9mSd. Accessed 6 July 2015.

Japan Times. 2015c. http://www.japantimes.co.jp/news/2015/04/23/national/politics-diplomacy/cabinet-minister-visitsyasukuni-shrine-shortly-abe-Xi-summit/\#.VcSYfJN9mSd. Accessed 1 July 2015.

Kamenetsky, Christa. 1972. Folklore as a Political Tool in Nazi Germany. The Journal of American Folklore 85(337): 221-235.

Kaufmann, F.W. 1942. Fichte and National Socialism. American Political Science Review 36(3): 460-470. 
Kershaw, lan. 2000. The Nazi Dictatorship: Problems and Perspectives of Interpretation. New York: Oxford University Press. Kielmansegg, Peter Graf. 2000. Nach der Katastrophe: Eine Geschichte des geteilten Deutschlands. Berlin: Siedler Verlag. Kingston, Jeff. 2010. Japan in Transformation, 1945-2010. Harlow, New York: Longman.

Kitschelt, Herbert. 1995. The Radical Right in Western Europe: A Comparative Analysis. Ann Arbor: University of Michigan Press.

Kraushaar, Wolfang. 2008. "Denkmodelle der 68er". In Die 68er Bewegung, ed. bpb. http://www.bpb.de/geschichte/ deutsche-geschichte/68er-bewegung/51820/denkmodelle. Acessed 17 January 2016.

Lebra, Joyce C. 1975. Japan's Greater East Asia Co-Prosperity Sphere in World War II: Selected Readings and Documents. Oxford: Oxford University Press.

Lee, Stephen J. 2003. Europe, 1890-1945. London, New York: Routledge.

Lewis, David C. 1993. Religious Rites in a Japanese Factory. In Religion and Society in Modern Japan, ed. Mark R. Mullins, Shimazono Susumu, and Paul L. Swanson, 157-170. Berkeley: Asian Humanities Press.

Ludtke, Alf. 1993. Coming to Terms with the Past: Illusions of Remembering, Ways of Forgetting Nazism in West Germany. The Journal of Modern History 65: 542-572.

Mochizuki, Mike M. 2010. The Yasukuni Shrine Conundrum: Japan's Contested Identity and Memory. In Northeast Asia's Difficult Past: Essays in Collective Memory, ed. Mikyoung Kim and Barry Schwartz, 31-52. London: Palgrave.

Mullins, Mark R. 1993. Introduction to Part 2: Religion and the State. In Religion and Society in Modern Japan, ed. Mark R. Mullins, Shimazono Susumu, and Paul L. Swanson, 75-80. Berkeley: Asian Humanities Press.

Nakane, Chie. 1970. Japanese Society. Berkeley: University of California Press.

Nationalrat der Nationalen Front des Demokratischen Deutschland/Dokumentationszentrum der staatlichen Archivverwaltung der DDR (ed.). 1965. Braunbuch. Kriegs- und Naziverbrecher in der Bundesrepublik. Berlin: Edition Ost.

Newman, Robert P. 1995. Truman and the Hiroshima Cult. East Lansing: Michigan State University Press.

NHK. 2015. Sanpi ga kikkō suru kenpō kaisei (The pros and cons of the constitutional amendment). http://www.nhk.or.jp/bunken/summary/research/report/2015_07/20150702.pdf. Accessed 15 August 2015.

Nihon Izokukai. Homepage. http://www.nippon-izokukai.jp/aboutus/. Accessed 6 December 2015.

Nijhuis, Ton. 2016. Export hit Vergangeneheitsbewältigung'. Germany and European integration as a role model for Korea and East Asia? Asian Journal of German and European Studies 1: 1-9.

Noelle, Elisabeth, and Erich Peter Neumann (eds.). 1956. Jahrbuch der Öffentlichen Meinung 1947-1955. Allensbach: Institut für Demoskopie.

Nozaki, Yoshiko. 2008. Education in Postwar Japan, 1945-2007: The Japanese history textbook controversy and lenaga Saburo's court challenges. London and New York: Routledge.

Pautz, Hartwig. 2010. Die deutsche Leitkultur: Eine Identitätsdebatte. Stuttgart: ibidem.

Payne, Stanley G. 1996. A History of Fascism, 1914-45. Madison: The University of Wisconsin Press.

Pearson, Keith Ansell. 1994. An Introduction to Nietzsche as Political Thinker: The Perfect Nihilist. Cambridge: Cambridge University Press.

Schmidt, Carmen. 2001. Sozialstruktur und politisches System in Japan. Marburg: Tectum.

Schmidt, Carmen. 2003. Kleines kommentiertes Wörterbuch zur Politik in Japan. Japanisch - Deutsch. Mit einem deutschjapanischen Stichwortverzeichnis. Marburg: Tectum.

Schmidt, Carmen. 2011. Der historische Machtwechsel in Japan vor dem Hintergrund von Wahlrecht und Wählerverhalten. Zeitschrift für Parlamentsfragen 1: 83-97.

Schmidt, Carmen. 2012. Japan nach Fukushima: Eine "Restrisikogesellschaft" im Aufbruch? Leviathan 41: 1-33.

Schmidt, Carmen. 2015. Civil Religion in Japan: From the Meiji Restoration to the Present Day. In Japan und das Problem der Moderne. Wolfgang Seifert zu Ehren, ed. Christian Uhl und Urs Matthias Zachmann, 416-440. München: ludicium.

Schmitt, Carl. 1934. Der Führer schützt das Recht. Deutsche Juristenzeitung 39(15): column 945-50.

Seeliger, Rolf, et al., eds. 1965-68: Braune Universität: deutsche Hochschullehrer gestern und heute, Dokumentation mit Stellungnahmen, vol. 1-6. München: Rolf Seeliger

Seitz, Norbert. 2007. Die Nachhaltigkeit eines neuen Patriotismus. Aus Politik und Zeitgeschichte (APuZ) 1-2: 8-13.

Shirer, William L. 1990. The Rise and Fall of the Third Reich: A History of Nazi Germany. New York: Simon \& Schuster.

Smith, Wooudruff D. 1980. Friedrich Ratzel and the Origins of Lebensraum. German Studies Review 3(1): 51-68.

Spiegel Umfrage. 1970. Kniefall angemessen oder übertrieben? Spiegel Umfrage über Willy BrandsTotenehrung am Ehrenmal im früheren Warschauer Ghetto. Der Spiegel (14.12.1970). http://www.spiegel.de/spiegel/print/d43822427.html. Accessed 12 May 2016.

Stackelberg, Roderick. 2007. The Rutledge companion to Nazi Germany. New York and London: Routledge.

Stockwin, J.A.A. 2003. Dictonary of the Modern Politics of Japan. London und New York: Routledge Curzon.

Sugimoto, Yoshio. 2003. An Introduction to Japanese Society. Cambridge: Cambridge University.

Swyngedouw, Jan. 1993. Religion in Contemporary Japanese Society. In Religion and Society in Modern Japan, ed. Mark R. Mullins, Susumu Shimazono, and Paul L. Swanson, 49-72. Berkeley: Asian Humanities Press.

Takayama, Peter K. 1988. Revitalization Movement of Modern Japanese Civil Religion. Sociological Analysis 48: 328-341.

Takayama, Peter K. 1993. The Revitalization of Japanese Civil Religion. In Religion and Society in Modern Japan, eds. Mark R Mullins, Shimazono Susumu, and Paul L Swanson, 105-120. Berkeley: Asian Humanities Press.

Takemae, Eiji. 2002. Inside GHQ: The Allied Occupation of Japan and Its Legacy (trans: Ricketts, Robert). New York: Continuum.

Tanaka, Yuki. 2013. Hiroshima and America's Crimes of War against the People of Japan (trans. Michiko Hase). AsiaPacific Journal. http://apjjf.org/-Yuki-Tanaka/4770/article.html. Accessed 15 August 2016.

McCurry, Justin. 2015. Do mention the war,' Merkel urges Japanese. Tokyo speech by German leader comes amid speculation that Japanese PM may water down previous expressions of remorse. The Guardian. https://www.theguardian.com/world/2015/mar/09/merkel-urges-japanese-confront-wartime-conduct. Accessed 15 Apirl 2016.

Tibi, Bassam. 1998. Europa ohne Identität? Die Krise der multikulturellen Demokratie. München: C. Bertelsmann. 
Tsunoda, Ryusaku, William De Bary, and Donald Keene. 1964. Sources of Japanese Tradition Vol. 2. New York: Columbia University Press.

van Deth, Jan W. 2001. Wertewandel im internationalen Vergleich: Ein Sonderweg? Aus Politik und Zeitgeschichte (APUZ) B 29: 23-30.

von Dirke, Sabine. 1997. All Power to the Imagination": The West German Counter Culture from the Student Movement to the Greens. Lincoln and London: University of Nebraska Press.

Vorländer, Hans. 2009. Die Deutschen und ihre Verfassung". Aus Politik und Zeitgeschichte (APuZ) 18-19: 8-18. http://www. bpb.de/apuz/32021/die-deutschen-und-ihre-verfassung?p=all\#footnodeid_2-2. Accessed 24 January 2016.

Walser, Martin. 1965. Unser Auschwitz. Kursbuch 1: 189-200.

Wetzel, Juliane. 2008. Holocaust Erziehung. In Geschichte und Erinnerung, ed. bpb. http://www.bpb.de/geschichte/ zeitgeschichte/geschichte-und-erinnerung/39843/holocaust-erziehung. Accessed 28 March 2016.

Wolfrun, Edgar .2008. Geschichte und Erinnerungskultur in der DDR und der BRD. In Geschichte und Erinnerung, ed. bpb. http://www.bpb.de/geschichte/zeitgeschichte/geschichte-und-erinnerung/39814/geschichte-dererinnerungskultur? $\mathrm{p}=$ all. Accessed 15 August 2015

Yahoo News. 2015. http://news.yahoo.com/japan-minister-visits-controversial-tokyo-war-shrine-afp-010329658.html. Accessed 15 August 2015 